\title{
RELIABILITY MODEL OF DIFFERENT WIND POWER PLANT CONFIGURATION USING SEQUENTIAL MONTE CARLO SIMULATION
}

\section{MODEL NIEZAWODNOŚCI RÓŻNYCH KONFIGURACJI ZESTAWU ELEKTROWNI WIATROWEJ OPARTY NA SEKWENCYJNEJ SYMULACJI MONTE CARLO}

\begin{abstract}
Paper presents an enhanced model for calculation of reliability indices for different wind power plants configuration concepts used over past two decades. The autoregressive - moving average (ARMA) model is used combined with the sequential Monte Carlo simulation in order to predict expected energy not served (EENS) more accurately during the failure. Statistical database of LWK (Land Wirtschafts Kammer) is used for determining different wind power plant configuration types component reliability (performance) used for calculating influence of individual wind power plant configuration concepts on expected energy not served. Furthermore, a comparison of the distribution of EENS of different wind power plants configuration concepts have been presented, as well as the influence of the predominantly mechanical and electrical components failures on both EENS and failure rates.
\end{abstract}

Keywords: wind turbine; components; reliability; failure rate; Monte Carlo, ARMA.

\begin{abstract}
W pracy przedstawiono udoskonalony model stużący do obliczania wskaźników niezawodności dla różnych koncepcji konfiguracji zestawów elektrowni wiatrowych jakie stosowano w ostatnich dwóch dziesięcioleciach. Wykorzystano autoregresyjny model średniej ruchomej (ARMA), który w połaczeniu z symulacja sekwencyjna Monte Carlo pozwala z większa dokładnościa przewidzieć oczekiwana wartość energii niedostarczonej (EENS) podczas awarii. Baza statystyczna LWK (Land Wirtschafts Kammer) postużyła autorom do określania niezawodności (wydajności) części składowych elektrowni wiatrowych przy różnych typach konfiguracji zestawu. Otrzymane wartości wykorzystano do obliczenia wpływu poszczególnych koncepcji konfiguracji zestawu elektrowni wiatrowej na oczekiwana wartość energii niedostarczonej. Ponadto, przedstawiono porównanie rozkładu EENS dla różnych koncepcji konfiguracji zestawu elektrowni wiatrowej jak również omówiono wplyw uszkodzeń części mechanicznych i elektrycznych elektrowni na EENS oraz awaryjność.
\end{abstract}

Stowa kluczowe: turbina wiatrowa; części składowe, niezawodność; awaryjność; Monte Carlo, ARMA.

\section{Introduction}

According to the International Energy Agency (www.iea.org) in 2009 total electricity generation share of the nuclear power plants was $13.4 \%$, natural gas $21.4 \%$, oil $5.1 \%$ and coal power plants $40.6 \%$, while share of renewables (without large hydropower plants -16.2 $\%)$ was $3.3 \%$. Those non-renewable power generation units, though generally highly dispatchable and reliable, have in turn huge environmental influence, especially on the global warming, due to the great share of fossil fuels usage [17].

In recent years, share of renewables in total electricity generation is increasing: excluding big hydropower plants, the greatest share in electricity generation from renewables is coming from the wind power plants. Total installed capacity in renewables in 2013 was 560 GW respectively, out of which $56.7 \%$ or $318 \mathrm{GW}$ from wind power plants [28]. In regard to a conventional power plant (thermal, hydro and nuclear) which implies adequacy of primary energy and constant power generation, wind power plants are depending on wind speed that is highly variable.

Due to the great increase of the capacity of wind power plants in recent years, their reliability is more and more important. That resulted in many wind turbine reliability models and methods being developed. However, due to the recent availability of long-term wind power plant statistics and fast development of wind turbine technology and size, it is important to continue developing new and more accurate wind turbine reliability models. This paper is an effort in that direction presenting advanced reliability modelling for different wind turbine types, taking into account different wind power plant configurations developed over the past years and component performance statistics.

The former developed reliability models of wind power plants in $[5,7,8,22,23,28]$ have so far related to the wind power plant as a whole. These reliability models have yielded a detailed overview of the impact of wind power plants on the reliability and availability, but they were not taking into account the impact of individual components of the each single wind power plant on the calculation of reliability indices of wind power plant. In [3] an analytical model is presented that describes in detail the reliability of wind power plant by taking into account diversity of the wind power plant configuration from the generator aspect. Also, according to [2] and described in chapter 2 , there are four dominant configuration groups of wind power plants differed by type of generator, by network connection, by power control and by speed rate.

\section{Wind turbine's construction characteristics}

Wind turbine's main components are namely: rotor (hub and blades), brake, gearbox, generator, electronic control system, yaw system, nacelle, drive train, anemometer and tower. According to [2], 
there are four typically configuration concepts of a wind turbine: Type A, Type B, Type C and Type D.

Type A configuration presents wind turbine with constant speed, stall power regulation and squirrel cage induction generator. Type B configuration corresponds to the limited variable speed wind turbine with variable generator rotor resistance, known as OptiSlip. It uses a wound rotor induction generator (WRIG) and has been used by the Danish manufacturer Vestas since the mid-1990s. The generator is directly connected to the grid [2]. Type C, which is known as the limited variable speed wind turbine with a wound rotor induction generator (WRIG) and partial scale frequency converter (rated at approximately $30 \%$ of nominal generator power) on the rotor circuit [2]. Type D configuration corresponds to the full variable-speed wind turbine, with the generator connected to the grid through a full-scale frequency converter. Some full variable-speed wind turbine systems have no gearbox [2].

\section{Statistical data of a wind turbine components}

For a wind turbine reliability assessment, it is very important to have statistical data on performances and failures of wind turbine components. Detailed data on performance of wind turbines were presented by Windstats [35]. Windstats is a commercial newsletter for the wind industry and records details of performance of wind turbines in many countries [33]. Tavner, Xiang and Spinato have performed detailed analysis of Windstats reliability data for German (WSD) and Danish (WSDK) wind turbines for 10-year period from October 1994 to September 2004 presented in [33]. Except the Windstats data, Spinato, Tavner, van Bussel and Koutoulakos in [31] have also analysed reliability data for wind turbines obtained from a survey performed by the Land Wirtschafts Kammer (termed in this paper LWK) in Schleswig Holstein, Germany. LWK data are based on 11-year long period. Also, data on the performance of wind turbines extracted from WMEP (Wissenschaftliches Mess und Evaluierungsprogramm) are available. WMEP data are based on 17-year period of research and include more than 1500 wind turbines. Those data were analysed and presented in $[13,16]$ and [32]. Other performance statistics of reliability of wind for Sweden, Germany and Finland were presented in [29] and [30]. In this paper will be used data from LWK database. In research presented in this paper, reliability analysis for type A conthe doubly fed induction generator (DFIG) concept, corresponds to

figuration of wind turbine will be performed using LWK database for wind turbine Nordex N52/N54, for type B configuration of wind turbine will be performed using LWK database for wind turbine Vestas V39 and for type D configuration of a wind turbine will be performed using LWK database for wind turbine Enercon E66. For type C configuration of wind turbine there are no available data and this type of configuration will not be taken in to consideration. Table 1 presents statistical data on the failure rates and downtimes of particular components of a wind turbine according to LWK database [31].

\section{Model description}

\subsection{Wind speed model}

When it comes to a reliability assessment of a wind turbine, it is very important to have data about wind speed because output power of wind turbine is directly dependent on wind speed as previously described. For the reliability assessment of a wind turbine, data about wind speed can be used directly or, as it will be described below, can be modelled. In the previous research wind speed with the time-series (autoregressive, moving average or autoregressive moving average model), Weibull, Rayleigh or normal distribution or Markov chain was modelled.

Billinton, Chen and Ghajar in [6] have modelled the wind speed with time series (autoregressive moving average - ARMA) and in described in detail. Also, many other authors have used ARMA model for wind speed modelling as in $[1,5,7,8,21,22,23,27,28]$. Deshmukh and Ramakumar in [11] have used a Weibull distribution for wind speed modelling. Also, Weibull distribution for wind speed modelling in $[3,10,12]$ and $[20]$ was used. Giorseto and Utsurogi in [14], Wang, Dai, Hui and Thomas in [34] and Attvwa and El-Saadany in [4] have used Rayleigh distribution for wind speed modelling. Normal distribution for wind speed modelling in $[15,18,19,25]$ and Markov chain in $[9,24,26]$ was used.

In this paper the wind speed model described in [6] is used. In this paper wind speed with the time series will be modelled. General form of the time series (ARMA model) is given with the following expression:

$$
y_{t}=\Phi_{1} y_{t-1}+\Phi_{2} y_{t-2}+\ldots \Phi_{n} y_{t-n}+\alpha_{t}-\Theta_{1} \alpha_{t-1}-\Theta_{2} \alpha_{t-2}-\ldots-\Theta_{m} \alpha_{t-m}
$$

Table 1. Reliability data for different wind turbine types according to LWK database [31]

\begin{tabular}{|c|c|c|c|c|}
\hline \multirow{2}{*}{$\begin{array}{l}\text { Wind turbine compo- } \\
\text { nent }\end{array}$} & \multicolumn{3}{|c|}{ Failure rate [1/year] } & \multirow{2}{*}{$\begin{array}{l}\text { Downtime [h/ } \\
\text { failure] }\end{array}$} \\
\hline & $\begin{array}{c}\text { Nordex N52/N54 } \\
\text { (Type A) }\end{array}$ & Vestas V39 (Type B) & $\begin{array}{l}\text { Enercon E66 } \\
\text { (Type D) }\end{array}$ & \\
\hline Electrical system & 0.28 & 0.34 & 0.50 & 255 \\
\hline Electronic system & 0.15 & 0.27 & 0.31 & 60 \\
\hline Generator & 0.11 & 0.09 & 0.13 & 160 \\
\hline Hydraulic system & 0.19 & 0.26 & - & 70 \\
\hline Yaw system & 0.12 & 0.10 & 0.17 & 60 \\
\hline Mechanical brake & 0.08 & 0.01 & 0.02 & 45 \\
\hline Sensors & 0.03 & 0.08 & 0.26 & 42 \\
\hline Anemometer & 0.13 & 0.06 & 0.07 & 4 \\
\hline Pitch control & - & 0.10 & 0.47 & 70 \\
\hline Rotor and blades & 0.46 & 0.17 & 0.14 & 125 \\
\hline Gearbox & 0.51 & 0.18 & - & 335 \\
\hline Air brake & 0.06 & - & - & 110 \\
\hline Shaft/bearings & 0.07 & - & 0.05 & 130 \\
\hline Other & 0.43 & 0.20 & 0.24 & 65 \\
\hline
\end{tabular}

Where: $\Phi_{i}=1,2, \ldots, n$ autoregressive parameters, $\Theta_{i}=1,2, \ldots, m$ moving average parameters, $\left\{\alpha_{t}\right\}$ white noise with normally distributed with mean zero and variance $\sigma_{a}^{2}$. Wind speed model according to [6] with the following equation can be expressed:

$$
V_{t}=\mu+y_{t}
$$

Where is: $V_{\mathrm{t}}-$ simulated wind speed in the hour $t, \mu$-mean value of the wind speed of the all observed measured data, $y_{\mathrm{t}}-$ time series of the wind speed described with expression (1).

\subsection{Wind power plant model}

In this chapter, enhanced reliability model of wind turbine is shown and de- 
scribed. New introduced and developed reliability model of wind turbine has the aim to give a detailed calculation of reliability indices of wind turbine. Output power of wind turbine with the following equation is presented:

$$
P=\left\{\begin{array}{cc}
0 & 0 \leq v_{t} \leq v_{c i} \\
\left(A+B v_{t}+C v_{t}^{2}\right) P_{r} & v_{c i} \leq v_{t} \leq v_{r} \\
P_{r} & v_{r} \leq v_{t} \leq v_{c o} \\
0 & v_{t} \geq v_{c o}
\end{array}\right.
$$

Where is: $P_{\mathrm{r}}-$ rated power of wind turbine, $v_{\mathrm{ci}}-$ cut in wind speed, $v_{\mathrm{r}}$ - rated wind speed, $v_{\mathrm{co}}-$ cut out wind speed $v_{\mathrm{t}}$ - wind speed. Coefficient's $A, B$ and $C$ can be calculated by:

$$
\begin{aligned}
& A=\frac{1}{\left(v_{c i}-v_{r}\right)^{2}}\left[v_{c i}\left(v_{c i}+v_{r}\right)-4\left(v_{c i} \cdot v_{r}\right)\left[\frac{v_{c i}+v_{r}}{2 v_{r}}\right]^{3}\right] \\
& B=\frac{1}{\left(v_{c i}-v_{r}\right)^{2}}\left[4\left(v_{c i}+v_{r}\right)\left[\frac{v_{c i}+v_{r}}{2 v_{r}}\right]^{3}-\left(3 v_{c i}+v_{r}\right)\right] \\
& C=\frac{1}{\left(v_{c i}-v_{r}\right)^{2}}\left[2-4\left[\frac{v_{c i}+v_{r}}{2 v_{r}}\right]^{3}\right]
\end{aligned}
$$

Wind turbine model with series reliability model is presented. Failure of any component of wind turbine causes outage of wind turbine. Failure rate of whole wind turbine $\lambda_{\mathrm{WT}}$ can be calculated by:

$$
\lambda_{W T}=\sum_{i=1}^{n} \lambda_{i}
$$

random number generated $U_{1}$ and $U_{2}$ must be transformed into time according to equations (7) and (8).

$$
\begin{aligned}
T T F & =-\frac{1}{\lambda} \ln U_{1} \\
T T R & =-\frac{1}{\mu} \ln U_{2}
\end{aligned}
$$

At the moment of failure and after, wind speed is continually measured. Electric energy not supplied during downtime depends on wind speed during downtime. Two similar failures in duration, but significantly different by expected energy not served (EENS) are presented in Figure 1.

Sequential Monte Carlo simulation ends when convergence conditions have been reached. If default number of simulations is executed without the desired conditions of convergence achieved, it is necessary to increase the number of simulations $N$.

The convergence criterion for stopping the simulation is applied on the slowest variable convergence. In this case, the expected energy not served (EENS) is the slowest variable convergence, and then sufficient accuracy of simulation is achieved. Coefficient of accuracy $\alpha$, for described case when the converges variable is expected energy not served (EENS), can be written by the following expression:

$$
\alpha=\frac{\sigma(E E N S)}{-}
$$

Where $\sigma(E E N S)$ represents the standard deviation of expected energy not served and $E \overline{E N} S$ represents average expected energy not served of all previous simulations. In this paper, as a condition of sufficient accuracy the value is set as: $\alpha=0.05$. Block diagram of the enhanced reliability model of wind power plant is shown in Figure 2.

Where is: $\lambda_{\mathrm{i}}$ - failure rate of $i$-th component of wind turbine. Since wind turbine is with series reliability model presented, then average downtime of whole wind turbine $r_{\mathrm{WT}}$ based on failure rates and downtimes of idividual components can be calculated by:

$$
r_{W T}=\frac{\sum_{i=1}^{n} \lambda_{i} \cdot r_{i}}{\sum_{i=1}^{n} \lambda_{i}}=\frac{1}{\mu_{W T}}
$$

Where is: $r_{\mathrm{i}}$ - downtime of $i$-th component of wind turbine, $\mu_{\mathrm{WT}}-$ repair rate of whole wind turbine.

Once all the required input data have been entered and wind speeds and the corresponding output power of wind power plant have been listed, calculation of the reliability index of wind power plant have been based on the sequential Monte Carlo simulation (SMCs). As previously stated, for sequential Monte Carlo simulation exponential distribution is assumed. An example of sequential Monte Carlo simulation is presented in Figure 1. Duration of the period of correct work or time to failure TTF and duration of failures time or time to repair TTR, wind speed and power output of the wind power plant are monitored and presented in Figure 1. For sampling TTF and TTR the

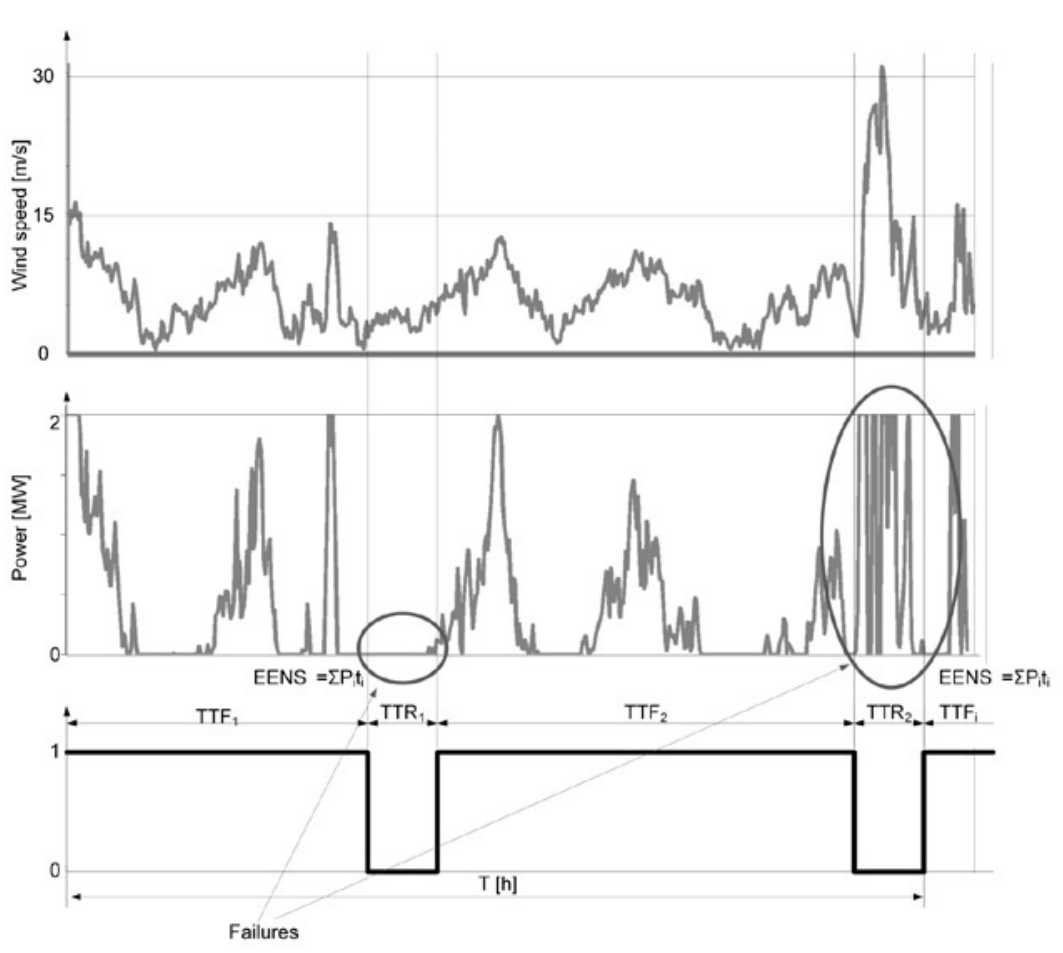

Fig. 1. An example of sequential Monte Carlo simulation 


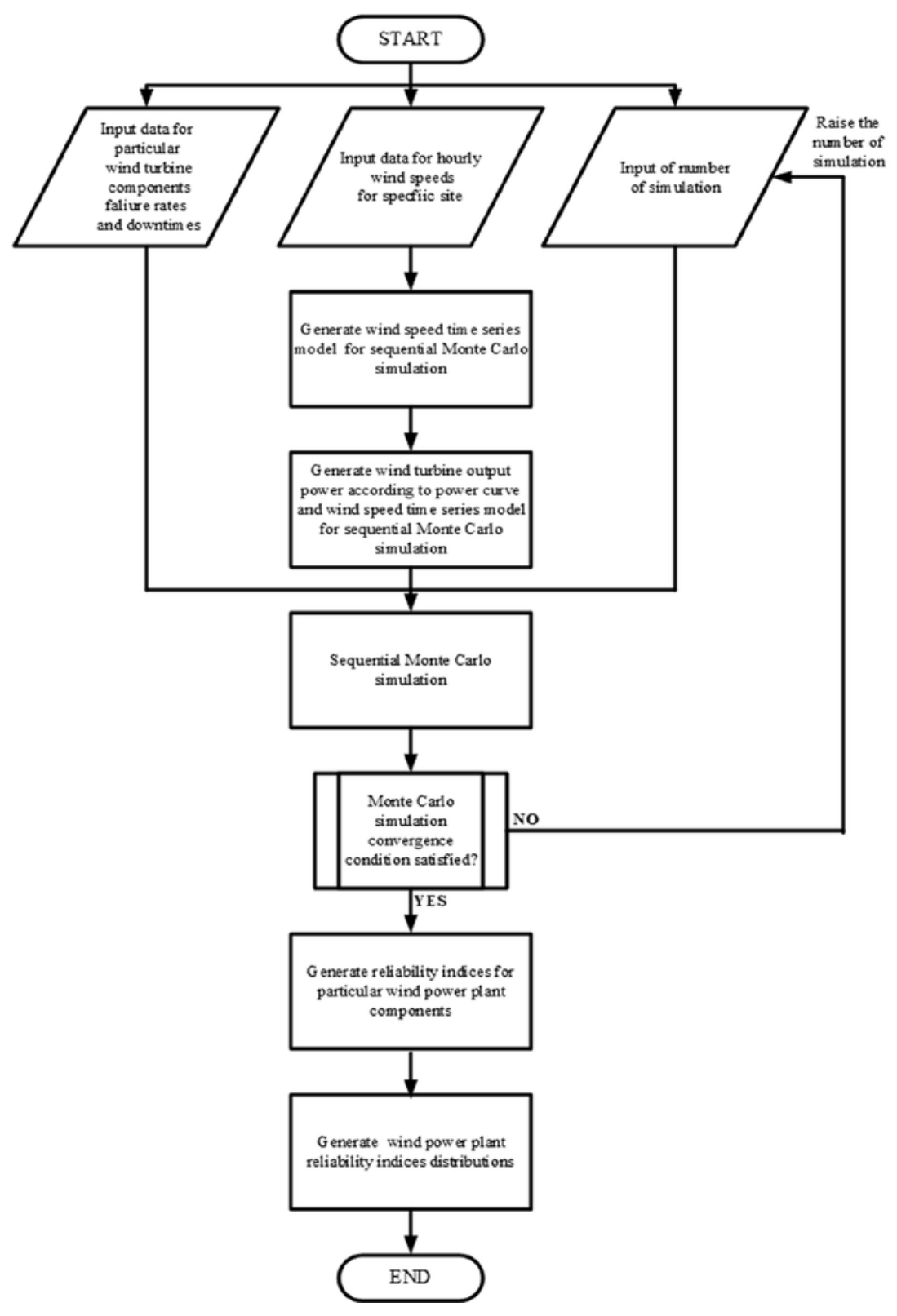

then used for enhanced reliability model of wind power plant. Wind speed model based on described procedure is then used in the Monte Carlo simulation.

The impact of individual components downtime of the wind power plant configuration types A, B and D on the EENS is shown in Figure 4.

From Figure 4 it is easy to see that gearbox has the largest contribution to the expected energy not served with the highest failure rate for type A. After the gearbox, electrical system, rotor and rotor blades failures have the greatest contributions to the EENS for type A. Downtimes of these three components (gearbox, electrical systems and rotor) caused about $48 \%$ of all wind power plant failures, but they are responsible for about $75 \%$ of the EENS. The remaining $60 \%$ downtime of wind power plant is responsible for only about $25 \%$ of the EENS.

From the same figure 4, it is obvious that electric system failures, gearbox failure, rotor and blades failures and hydraulic system failures have the largest contribution to the EENS for type B. Electric system has also the highest failure rate. Electronic control system has the second highest failure rate, but also has significantly smaller contribution to the total EENS. Failures of electric system and gearbox failures caused about $28 \%$ of all downtime of the wind power plant. On the other hand, failure of above mentioned components are responsible for almost $60 \%$ of the EENS. Remaining components failures make up about $72 \%$ of downtimes, but they are responsible for only about $40 \%$ of power plant's EENS, configuration type B.

It is very clear from Figure 4 that the electric system is the most unreliable component which caused the largest part of expected energy not served of wind power plant, configuration type D. The EENS, due to failures of electric system is $40.39 \mathrm{MWh} /$ year. The rotor blades (pitch control) failures followed according to the partial amount of EENS is $10.93 \mathrm{MWh} /$ year.

A comparison of the distribution of EENS of the wind power plants configuration types A, B and D is shown in Figure 5.

The comparison of absolute contributions of predominantly mechanical and electrical components fail-

Fig. 2. Block diagram of wind turbine reliability model

\section{Results}

In this example, enhanced reliability model of the wind power plant is applied for the calculation of reliability indices of several different wind power plant configurations, based on concepts of type A, B and D. Data on the failure rates and downtimes of wind power plant configuration types A, B and D have already been presented in Table 1 . The wind power plant which will be used as a case study of enhanced reliability model to get reliability indices has the following data: $P_{\mathrm{r}}=2 \mathrm{MW}, v_{\mathrm{ci}}=5 \mathrm{~m} / \mathrm{s}$, $v_{\mathrm{r}}=12 \mathrm{~m} / \mathrm{s}, v_{\mathrm{co}}=25 \mathrm{~m} / \mathrm{s}$.

To model wind speed "System identification Tool" after ARMA model ARMA $(5,0)$ is obtained, further on as AR (5) abbreviated. The part of wind speed sequence is presented in Figure 3. Actual measured wind speeds are marked with a black line, while simulated values of wind speed using the AR (5) model are illustrated with blue lines. The resulting autoregressive parameters of AR (5) model are: $\Phi_{1}=0.9635$, $\Phi_{2}=-0.06591, \Phi_{3}=0.03536, \Phi_{4}=0.0042$ and $\Phi_{5}=0.05521$. Having obtained the parameters of ARMA model, they are

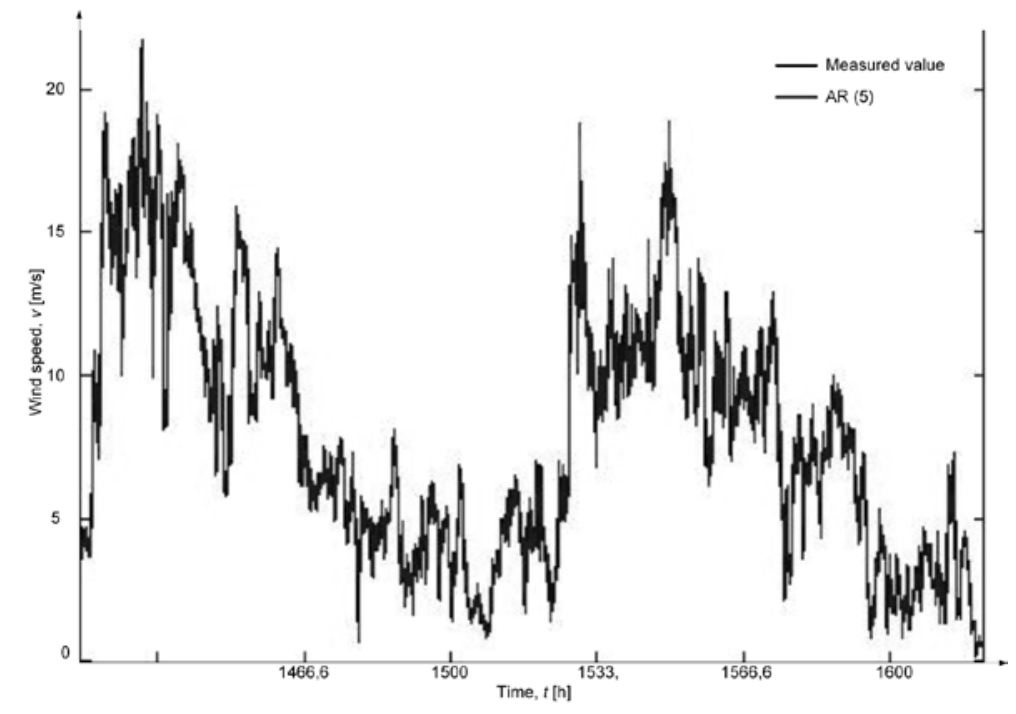

Fig. 3. An example of the simulated sequence of wind speed 


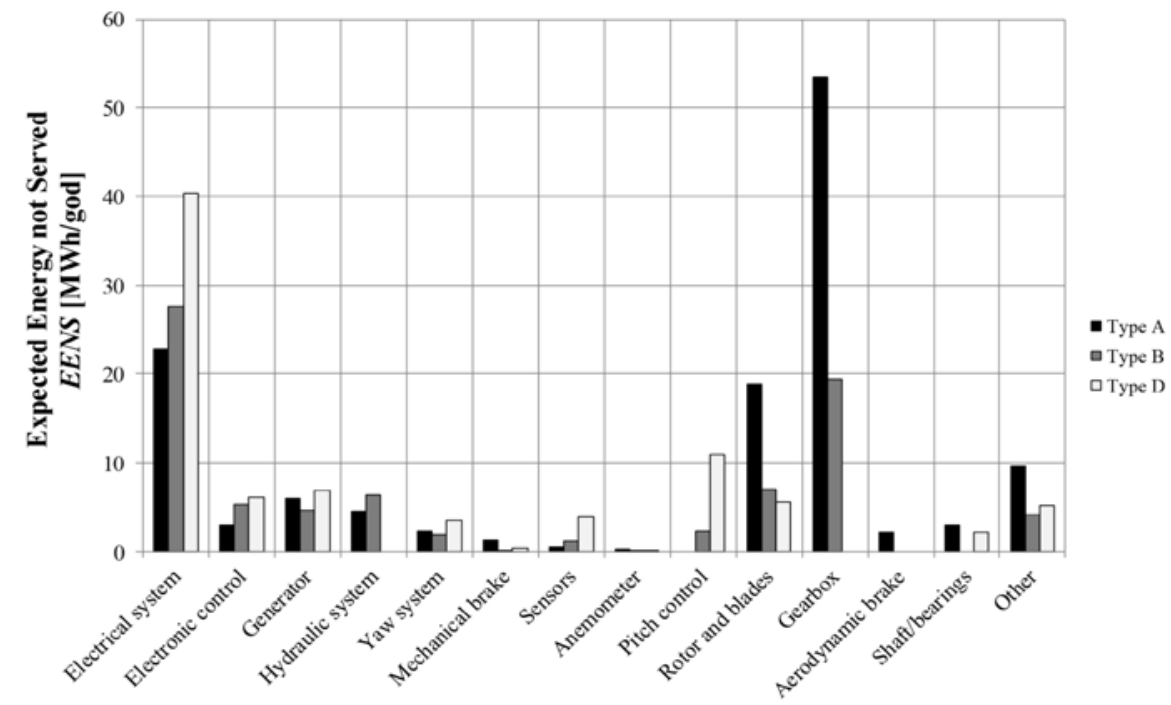

Fig. 4 Comparison of the EENS caused by failures of individual components of wind power plant for configuration concepts $A, B$ and $D$

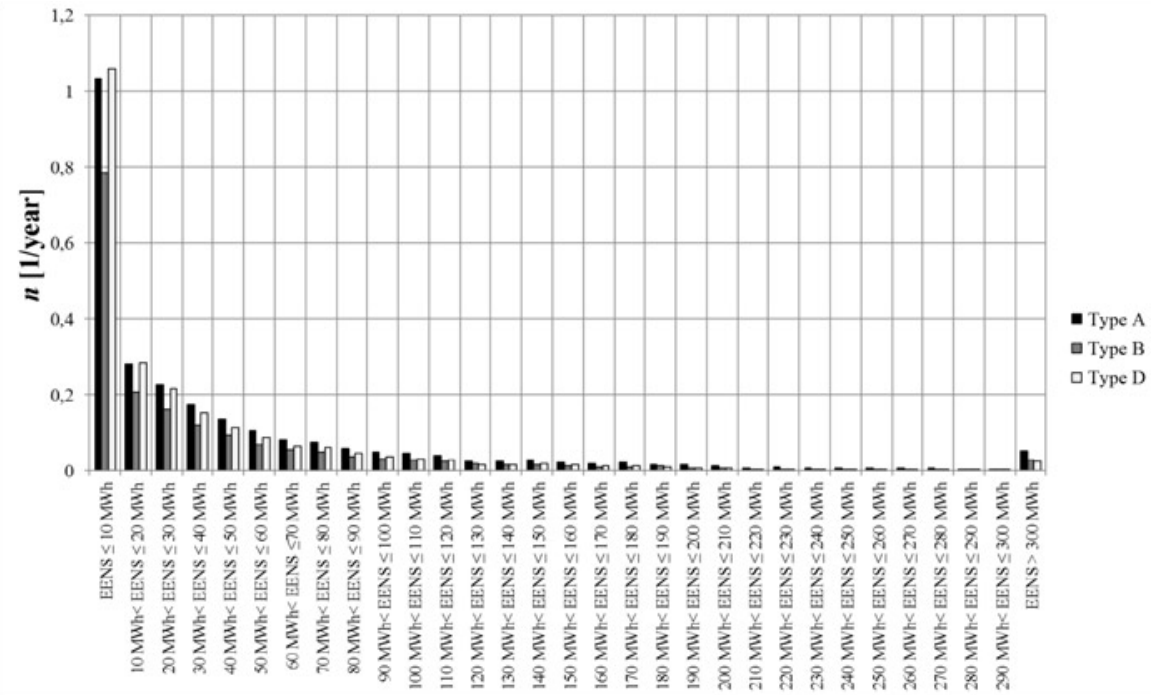

Fig. 5. A comparison of the distribution of EENS of the wind power plant configuration types $A, B$ and $D$ tion type $\mathrm{B}$, electrical components of the wind power plant configuration type A and mechanical components of wind power plant configuration type $\mathrm{D}$, respectively. A comparison of the relative contribution to expected energy not served caused by mechanical and electrical components of the wind power plants of all analysed configuration types (A, B and D) is presented in Figure 7. Shares of mechanical and electric components failure rates in the overall intensity of downtime for wind power configuration types A, B and D are illustrated in Figure 8.

\section{Conclusion}

The paper presents the availability and expected energy not served calculation of different type of wind turbines based on the statistical data on the performance of wind turbine components. Recently installed wind turbines in Germany (after 2008) have, in general, three blades, pitch power regulation, variable speed and synchronous or double-fed induction generator. Those characteristics correspond to wind turbine configuration concepts $\mathrm{C}$ and $\mathrm{D}$. It can therefore be expected that newly installed wind turbine in near future will have, in general, configuration concept $\mathrm{C}$ or $\mathrm{D}$, while on the other hand, many wind turbines currently in operation have configurations concepts A or B. Therefore results of the performed availability analysis of all configuration concepts presented in this paper can be used for reliability modelling of both operation of the existing and planning and design of new wind turbines which is the focus of the future research.

Failures of predominantly mechanical components in wind power plant configuration of type A are responsible for about $67 \%$ of the expected energy not served, in wind power plant configuration type $\mathrm{B}$ mechanical components are responsible for $48 \%$, and at least in wind power configuration type $\mathrm{D}$ for about $18 \%$. On the other hand, failures of mainly electrical components in wind power configuration of type $\mathrm{A}$ are responsi- ures of wind power plant, configuration types A, $\mathrm{B}$ and $\mathrm{D}$, to EENS is presented in Figure 6.

The most significant contribution to the EENS of wind power plant, configuration type A is caused by mechanical components, as presented in Figure 6. For wind power plant of configuration type $\mathrm{B}$, mechanical components failures and electric system components failures have fairly uniform contribution to EENS, while for wind power plant configuration type $\mathrm{D}$, the most significant contribution to the EENS is caused mostly by failures of the electrical components. If absolute contributions of all components in all three analysed wind power plant configurations are compared (Figure 6), the largest contributions to the EENS are caused by: mechanical components of the wind power plant configuration type A, electrical components wind power plant configuration $\mathrm{D}$, mechanical and electrical components of the wind power plant configura-

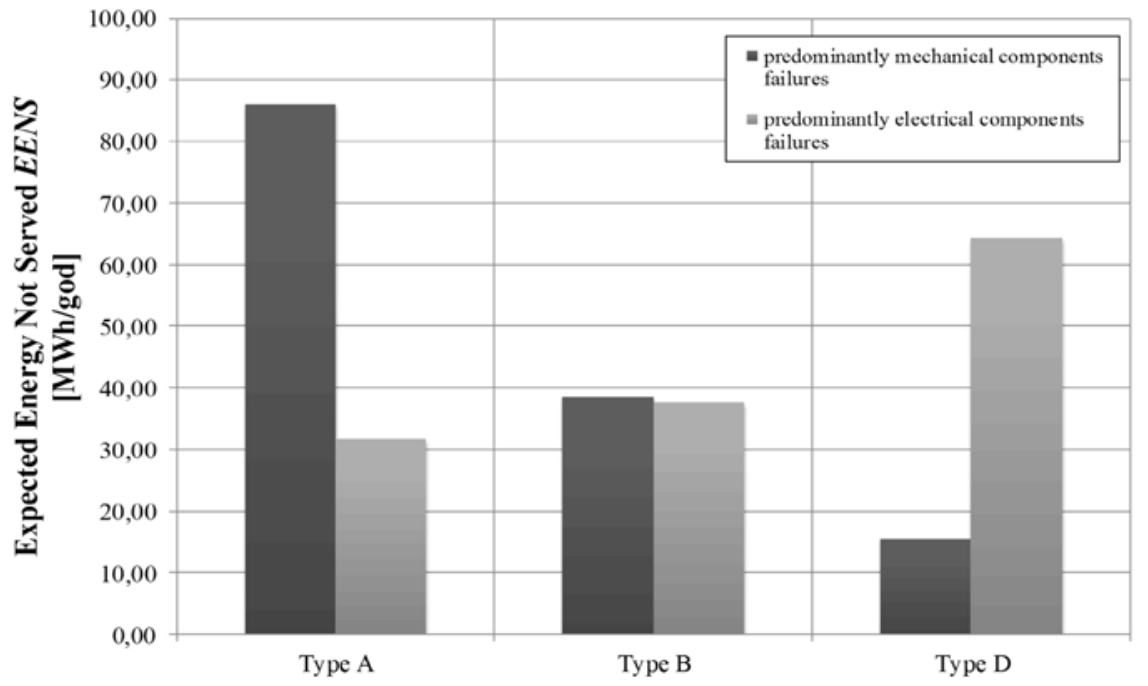

Fig. 6. The comparison of absolute contributions of predominantly mechanical and electrical components failures of wind power plant, configuration types $A, B$ and $D$, to EENS 


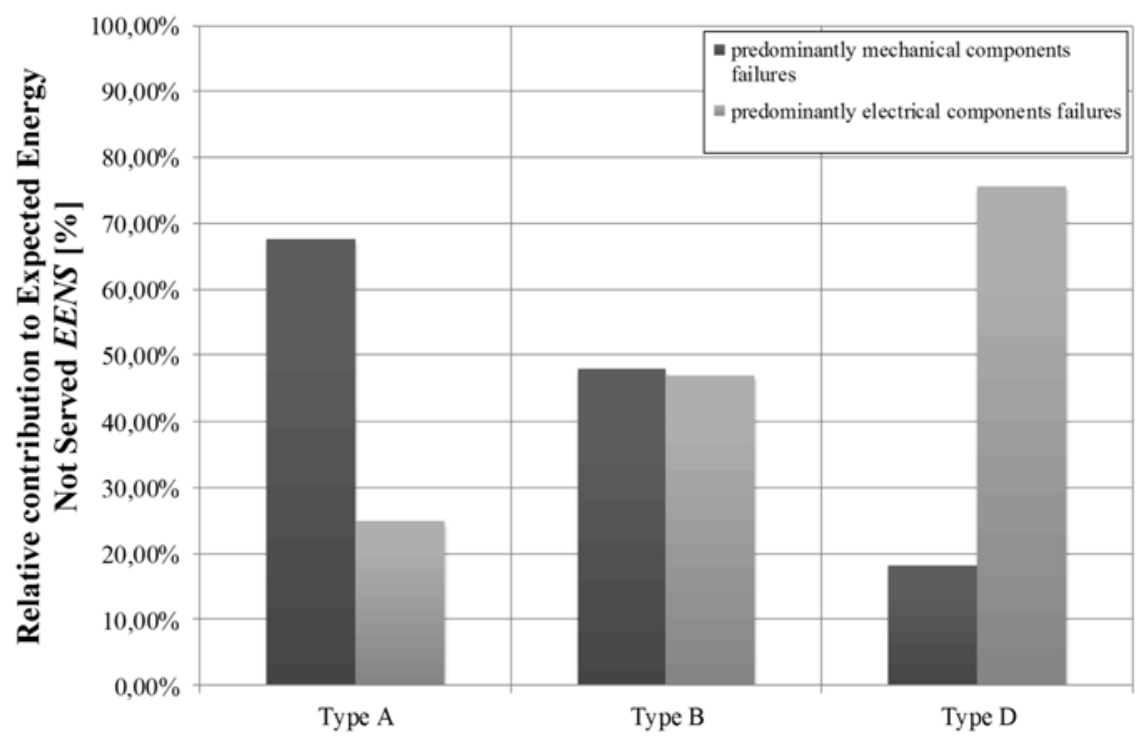

Fig. 7. Comparison of relative contribution to EENS, caused by mechanical and electrical components of the wind power plants of all analysed configuration types (A, $B$ and $D)$

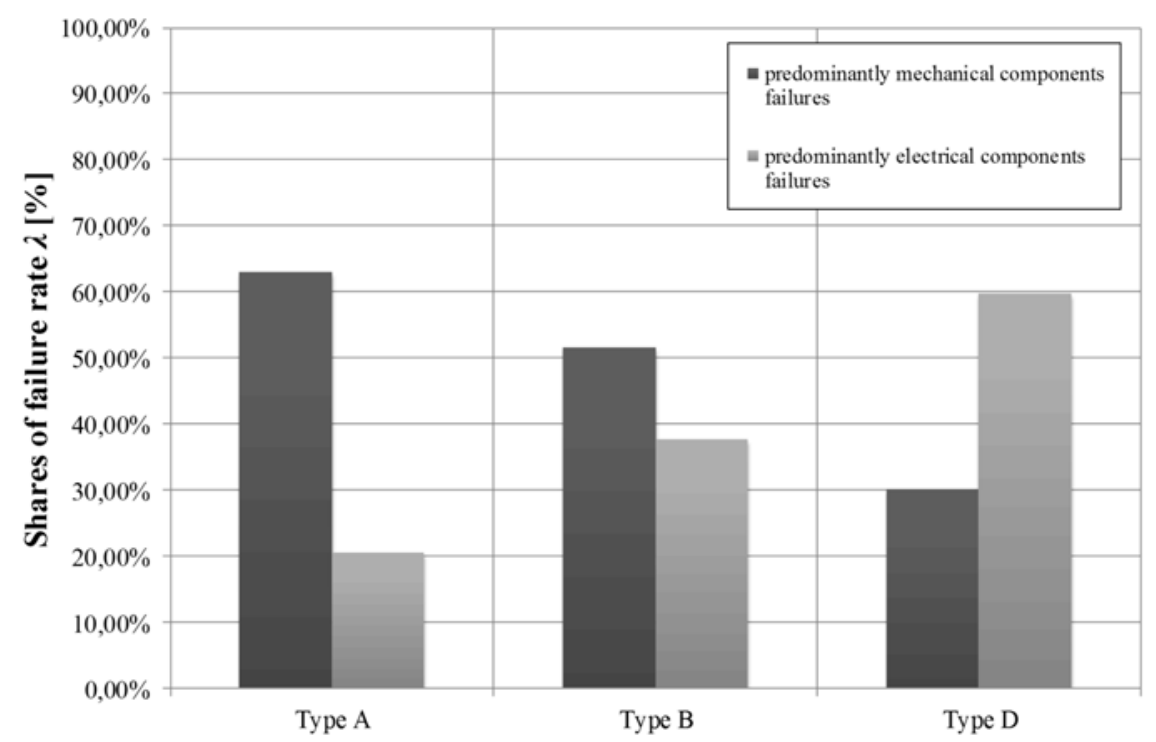

Fig. 8. Shares of failure rates of mechanical and electric components in the overall failure rates for wind power configuration types $A, B$ and $D$

ble for about $25 \%$ of the expected energy not served, in wind power plant configuration of type B electrical components are responsible for about $47 \%$, and in wind power plant configuration type $\mathrm{D}$, they are responsible for as much as $75 \%$.

The main reason why failures of mechanical components in wind power plant configuration type $\mathrm{D}$ have a contribution of only about $18 \%$ to the expected energy not served is that they have not transmission gearbox, which is previously described as a component with major contribution to the expected energy not served in wind power plant configuration of type $\mathrm{A}$ and also as a component with the second largest contribution to the EENS in wind power plant configuration type B (after the electrical system). Additional reason for mechanical components have such neglected cause of total failures in wind power plant configuration $\mathrm{D}$ is that the wind power plant configuration type $\mathrm{D}$, as already stated, has no hydraulic but rather electric actuators (for example in rotor blades control position system). Finally, the wind power plant configuration type D has no hydraulic system and there- fore there are no contributions of the component failures on EENS.

On the other hand, the reason why failures of mainly electrical components of the wind power plant configuration type D are responsible for about $75 \%$ of the EENS is that the hydraulic actuators have been replaced by electric. In this case, wind power plant configuration type $\mathrm{D}$ have synchronous generators that have lower rotating speed, which means increasing number of pole pairs and increasing number of electric windings - according to [31], it might be one reason for the higher intensity downtime of generators and electrical systems. Another reason why the wind power plants configuration type D have significant contribution of failures of electrical components in overall expected EENS, is that they have converters with full frequency regulation, unlike other types of wind power converters.

Wind power plants configuration type B have a fairly uniform contribution to expected energy not served due to failures of mechanical components, as well as to failures of electric components. Unlike wind power plant configuration type $\mathrm{D}$, the wind power plant configuration type B have a gearbox, as well as the hydraulic system, so these are reasons why failures of mechanical components have a greater contribution to the expected energy not served. On the other side, the wind power plants, configuration type B have no electric actuators in a system such as rotation of wind power plant or in the system for the rotation of the rotor blades. Wind power plant configuration type $\mathrm{B}$ has induction generator with slip rings, which is more robust than generators in wind power plant configuration type $\mathrm{D}$, without converter and frequency controlling unit, and these are the reasons why it has smaller contribution to expected energy not served, due to failures of electrical components in relation to the wind power plants configuration type $\mathrm{D}$.

Wind power plants configuration type A has the highest EENS caused by failures of mainly mechanical components. One reason is that wind power plants configuration Type A have gearbox similar as wind power plants configuration type B whose failures have quite significant contribution to EENS. Furthermore, it can be noted that the significant contribution to EENS have failures of rotor and rotor blades from all mechanical components. Wind power plants configuration type A opposed to the wind power plants configuration type $\mathrm{B}$ and $\mathrm{D}$, have the power regulation by intentionally loosing of wind speed achieved by aerodynamic design of the rotor blades (stall control). In this case, there is no possibility for the regulation of the angle of the rotor blades, causing increase of mechanical forces and stresses of the rotor blades. This may be the reason for a greater contribution of mechanical components failure to the EENS. On the other hand, the reason why the wind power plant configuration type A has the smallest contribution of electric components failures to EENS (both in absolute and relative amount) may be that this type of configuration has a quite robust squirrel-cage induction generator and also there are no power electronic components (frequency converter). 


\section{References}

1. Abul'Wafa A R. Reliability/cost evaluation of a wind power delivery system. Electric Power Systems Research 2011; 81: 873-879, http:// dx.doi.org/10.1016/j.epsr.2010.11.028.

2. Ackermann, T. Wind Power in Power Systems. Wiley, 2005, http://dx.doi.org/10.1002/0470012684.

3. Arabian-Hoseynabadi H, Oraee H, Tavner P J. Wind turbine productivity considering electrical subassembly reliability. Renewable Energy 2010; 35: 190-197, http://dx.doi.org/10.1016/j.renene.2009.04.014.

4. Attwa Y M, El-Saadany E F. Wind Based Distributed Generation; Uncertainties and planning Obstacles. Proceedings of IEEE Power Engineering Society General Meeting, Tampa, USA, June 2007: 1-5, http://dx.doi.org/10.1109/pes.2007.385800.

5. Billinton R, Bagen. A Sequential Simulation Method for the Generating Capacity Adequacy Evaluation of Small Stand - Alone WECS. IEEE Proceedings of Canadian Conference on Electrical and Computer Engineering 2002; 1: 72-77.

6. Billinton R, Chen H, Ghajar R. Time-series models for reliability evaluation of power systems including wind energy. Microelectronics Reliability 1996; 36: 1253-1261, http://dx.doi.org/10.1016/0026-2714(95)00154-9.

7. Billinton R, Gao Y. Multistate Wind Energy Conversion System Models for Adequacy Assessment of Generating Systems Incorporating Wind Energy. IEEE Transactions on Energy Conversion 2008; 23: 163-170, http://dx.doi.org/10.1109/TEC.2006.882415.

8. Billinton R, Hua C, Ghajar R. A sequential Simulation Technique for Adequacy Evaluation of Generating Systems Including Wind Energy. IEEE Transactions on Energy Conversion 1996; 11: 728-734, http://dx.doi.org/10.1109/60.556371.

9. Castro Sayas F, Allan N R. Generation availability assessment of wind farms. IET Generation, Transmission and Distribution, 1996; 143; 507-518, http://dx.doi.org/10.1049/ip-gtd:19960488.

10. D'Annunzio C, Santoso S. Wind power generation reliability analysis and modelling. Proceedings of IEEE Engineering Society General Meeting, San Francisco, USA, 2005; 35-39.

11. Deshmukh R G, Ramakumar R. Reliability Analysis of combined wind-electric and conventional generation systems. Solar Energy 1982; 28; 345-352, http://dx.doi.org/10.1016/0038-092X(82)90309-7.

12. Ehsani A, Fotuhi M, Abbaspour A, Ranjbar A M. An Analytical Method for the Reliability Evaluation of Wind Energy Systems. Proceedings of IEEE Region 10 TENCON, Melbourne, Australia, November 2005; 1-7, http://dx.doi.org/10.1109/tencon.2005.300832.

13. Faulstich S, Lyding P, Tavner P J. Effects of Wind Speed on Wind turbine Availability. Proceedings of EWEA 2011, Brussels, Belgium, March 2011.

14. Giorsetto P, Utsurogi K F. Development of a new procedure for reliability modeling of wind turbine generators. IEEE Transactions on Power Apparatus and Systems 1983: 134-143, http://dx.doi.org/10.1109/TPAS.1983.318006.

15. Haghifam M R, Omidvar M. Wind Farm Modeling in Reliability Assessment of Power System. Proceedings of International Conference on Probabilistic Methods Applied to Power Systems, Stockholm, Sweden, June 2006: 1-5, http://dx.doi.org/10.1109/pmaps.2006.360414.

16. Hahn B, Durstewitz M, Rohrig K. Reliability of wind turbines - Experiences of 15 years with 1500 WTs. (Institut für Solare Energieversorgungstechnik (ISET), Verein an der Universität Kassel, Kassel), Germany, 2006

17. International Energy Agency. www.iea.org, accessed November 2012

18. Jaeseok C, Jeongje P, Kyeonghee C, Taegon O, Shahidehpour M. Probabilistic Reliability Evaluation of Composite Power Systems Including Wind Turbine Generators. Proceedings of International Conference on Probabilistic Methods Applied to Power Systems, Singapore, Singapore, June 2010: 802-807.

19. Kaigui X, Billinton R. Energy and reliability benefits of wind energy conversion systems. Renewable Energy 2011; 36: 1983-1988, http:// dx.doi.org/10.1016/j.renene.2010.12.011.

20. Karaki S H, Chedid R B, Ramadan R. Probabilistic Performance Assessment of Wind Energy Conversion Systems. IEEE Transactions on Energy Conversion 1999; 14: 217-224, http://dx.doi.org/10.1109/60.766986.

21. Karki R, Billinton R. Cost-Effective Wind Energy Utilization of Reliable Power Supply. IEEE Transactions on Energy Conversion 2004; 19: 435-440, http://dx.doi.org/10.1109/TEC.2003.822293.

22. Karki R, Hu P, Billinton R. Reliability Evaluation of a Wind Power Delivery System Using an Approximate Wind Model. Proceedings of the 41st International Universities Power Engineering Conference, Newcastle, UK, September 2006: 113-117, http://dx.doi.org/10.1109/ UPEC.2006.367726.

23. Karki R, Hu P. Wind Power Simulation Model for Reliability Evaluation. Proceedings of Canadian Conference on Electrical and Computer Engineering, Saskatoon, Canada, May 2005: 541-544, http://dx.doi.org/10.1109/ccece.2005.1556988.

24. Leite A P, Borges C L T, Falcao D M. Probabilistic Wind Farms Generation Model for Reliability Studies Applied to Brazilian Sites. IEEE Transactions on Power Systems 2006; 21: 1493-1501, http://dx.doi.org/10.1109/TPWRS.2006.881160.

25. Liang W, Jeongje P, Jaeseok C, El-Keib A A, Shahidehpour M, Billinton R. Probabilistic Reliability Evaluation of Power Systems Including Wind turbine Generators Using a Simplified Multi State Model: A case Study. Proceedings of IEEE Power \& Energy Society General Meeting, Calgary, Canada, July 2009: 1-6.

26. Manco T, Testa A. A Markovian Approach to Model Power Avaliability of a Wind Turbine. Proceedings of IEEE Power Tech, Lausanne, Switzerland, July 2007: 1256-1261.

27. Peng W., Billinton R. Reliability Benefit Analysis of Adding WTG to a Distribution System. IEEE Transactions on Energy Conversion 2001; 16: 134-139, http://dx.doi.org/10.1109/60.921464.

28. Renewables 2013 - Global Status Report. http://www.ren21.net, accessed January 2014

29. Ribrant J, Bertling L. Survey of Failures in Wind Power Systems With Focus on Swedish Wind Power Plants During 1997 - 2005. IEEE Transactions on Energy Conversion 2007; 22: 167-173, http://dx.doi.org/10.1109/TEC.2006.889614.

30. Ribrant, J. Reliability performance and maintenance - A survey of failures in wind power systems, Stockholm: Master thesis, KTH School of Electrical Engineering, 2006.

31. Spinato F, Tavner P J, Van Bussel G J W, Koutoulakos E. Reliability of wind turbine subassemblies. IET Renewable Power Generation 2008; 3: 387-401, http://dx.doi.org/10.1049/iet-rpg.2008.0060. 
32. Tavner P J, Greenwood D M, Whittle M W G, Gindele R, Faulstich S, Hahn B. Study of weather and location effects on wind turbine failure rates. Wind Energy 2012; 16: 175-187, http://dx.doi.org/10.1002/we.538.

33. Tavner P J, Xiang J, Spinato F. Reliability Analysis for Wind Turbines. Wind Energy 2007; 10: 1-18, http://dx.doi.org/10.1002/we.204.

34. Wang X, Dai Hui Z, Thomas R J. Reliability Modeling of Large Wind Farms and Associated Electric Utility Interface Systems. IEEE Transactions on Power Apparatus and Systems 1984: 569-575, http://dx.doi.org/10.1109/TPAS.1984.318746.

35. Windstats. www.windstats.com, accessed November 2010.

\section{Danijel TOPIĆ \\ Faculty of Electrical Engineering \\ Josip Juraj Strossmayer University of Osijek \\ Ulica kneza Trpimira 2b, 31000 Osijek, Croatia}

\section{Damir ŠLJIVAC}

Faculty of Electrical Engineering

Josip Juraj Strossmayer University of Osijek

Ulica kneza Trpimira 2b, 31000 Osijek, Croatia

\section{Marinko STOJKOV}

Mechanical Engineering Faculty

Josip Juraj Strossmayer University of Osijek

Trg Ivane Brlić Mažuranić 2, 35000 Slavonski Brod, Croatia

E-mails: danijel.topic@etfos.hr, damir.sljivac@etfos.hr, mstojkov@sfsb.

$\mathrm{hr}$ 